Disponível em

http://www.anpad.org.br/rac

RAC, Rio de Janeiro, v. 17, n. 3, art. 5, pp. 350-367, Maio/Jun. 2013

$(\mathrm{oc})$ EY-No

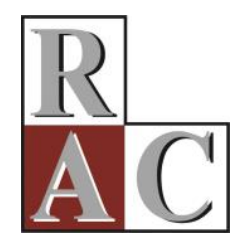

\title{
Characteristics and Performance of Knowledge Networks in the Biotechnology Sector
}

Diego de Queiroz Machado E-mail: diegoqueirozm@yahoo.com.br Universidade de Fortaleza - PPGA/UNIFOR UNIFOR, Bloco Q, Sala 3, Av. Washington Soares, 1321, Engenheiro L. Cavalcante, Fortaleza, CE, 60811-905, Brasil.

Ana Silvia Rocha Ipiranga E-mail: anasilviaipi@uol.com.br Universidade Estadual do Ceará - UECE Av. Paranjana, 1700, Campus do Itaperi, Fortaleza, CE, 60714-903, Brasil. 


\title{
Resumo
}

Esta pesquisa teve como objetivo analisar as propriedades e tipologias de uma rede do setor da biotecnologia em relação aos seus relacionamentos, atributos e desempenho em pesquisa e produção de inovações. Para este fim, escolheu-se, como campo empírico, a Rede Nordeste de Biotecnologia, usando-se, para tanto, relatórios de patentes produzidas pela rede como fonte de dados. A fim de acompanhar as redes de relacionamento entre os membros, grupos, instituições e projetos, ferramentas de análise de redes sociais foram utilizadas, dessa maneira, tornando possível a construção de matrizes de relacionamento entre laboratório e empresas e, por último, entre pesquisadores. No total, foram identificados 117 pesquisadores, distribuídos em 18 centros de pesquisa e 47 laboratórios ou empresas. Seus projetos estão distribuídos em três áreas principais: agricultura, indústria e saúde, sendo a última a mais forte das três áreas, com mais patentes produzidas e mais instituições envolvidas em pesquisas. A fraca densidade apresentada pela rede em foco, em todos os níveis de análise, reforça a necessidade de estratégias de integração e indica a possibilidade de novas relações entre os agentes que ainda estão isolados. No entanto, isso não diminui a sua importância para o desenvolvimento econômico na região em que atua.

Palavras-chave: inovação; redes sociais; biotecnologia; relatórios de patentes; Rede Nordeste de Biotecnologia.

\begin{abstract}
This research aimed to analyze the properties and typologies of a biotechnology sector network with regard to their relationships, attributes and performance in research and production of innovations. For this purpose, it had as its empirical field the Northeast Biotechnology Network, using patent reports produced by the network as a data source. In order to track the relationship networks between members, groups, institutions and projects, social networking analysis tools were used, making it possible to construct relationship matrices between the laboratories and companies and, lastly, researchers. In total, 117 researchers were identified, distributed among 18 research centers and 47 laboratories or companies. Their projects are distributed across three main areas: agriculture, industrial and health, the latter being the strongest of the three with more patents produced and more institutions involved in research. The weak density presented by the network, at all analysis levels, strengthens the necessity for integration strategies. Also, it indicates the possibility for new relationships between agents that are still isolated. However, it does not diminish its importance for economic development in the region in which it operates.
\end{abstract}

Key words: innovation; social networks; biotechnology; patent reports; Northeast Biotechnology Network. 


\section{Introduction}

There are times that the production of innovations ceased to be viewed as a linear process, exogenous and predictable based on the economy. On the contrary, its complexity has been shown to be increasingly in evidence, being reflected in diverse elements that influence its development and dissemination. Likewise, over the past few decades, its importance for the development of economies and societies has had an increased recognition by governments, organizations and individuals, keeping this theme at the center of discussions about economic and social progress and growth.

In defense of the complexity that permeates the development of new technologies, authors such as Nelson and Winter (1982), Freeman and Perez (1988), Dosi (1988), Tunzelmann (1995), Fagerberg (2005), Pavitt (1990, 2005), Smith (2005) and Rosenberg (2006), among others, have focused their efforts on demonstrating the various research aspects that influence innovative activity. Their research shows how the latter may differ in terms of type of activity, field of knowledge, type of innovation, region or sponsor country, company size, organizational strategy and, especially, the category of industry and economy in which it develops.

In addition, over the century its own innovative process changed these elements. The last stage of this evolution is an innovation model that involves the concept of open innovation as proposed by Chesbrough $(2003,2006)$, in which development strategy takes place within centralized or decentralized collaborative networks. Hence the importance of production networks and knowledge transfer in the development and promotion of innovations.

In this manner, the importance of research efforts that seek to understand all the complexity and heterogeneity of the innovation process and technology transfer, especially within the dynamics of knowledge networks and innovation in recently industrialized economies is clear. In addition, sectors highly based on science, as is the case of the biotech industry, have characteristics which should be considered. Given the scarcity of studies focusing on the formation and updating of innovation networks within this sector, our research aims to identify and understand elements and processes that interfere with the development and dissemination of new technologies. This is due to the fact that a vast majority of studies only focus on networks composed of biotech companies.

Based on these considerations and adopting as a premise that knowledge produced in a social network circulates between its various actors, the overall purpose of the research was: to analyze a biotechnology social network's properties and typologies with regard to their relationships, attributes and performance in innovation research and production. To this end, this study employed a qualitative and descriptive approach, using Northeast of Biotechnology Network (Renorbio) as the empirical field, whose main focus of activities are concentrated in its Postgraduate Studies Center, which involves thirty institutions from Brazil's northeast region. Being a network geared toward knowledge production and innovations in biotechnology, its importance as an agent of economic development makes it stand out within the sector. Accordingly, the knowledge of its characteristics and properties, as well as its organizational research structure and practices and knowledge transfer, are necessary.

We used reports of patents developed by actors (researchers or institutions) who were participants in Renorbio over the past five years as data sources. This is due to the wealth of information contained in them, especially in regard to the researchers involved, market characteristics and technological areas related to innovation. The information extracted from these reports was considered according to four categories of data: researchers, institutions (laboratories and companies); research area; and potential markets. Such categories were organized and analyzed by use of social network analysis software Ucinet and NetDraw. These emphasized the main indicators of social networks: density, degree of centrality, index of centralization, degree of intermediation and degree of proximity.

Therefore, it is expected that the focus and approach chosen for this study will contribute to a greater understanding of the role of knowledge networks for the development of innovations within 
the biotechnology sector, encouraging the production of more research in this area, which is still insufficient. In addition, such an effort aims to enable the future development of strategic models for the management of these new technologies, fostering economic and social development of the regions where they are located.

\section{The Process of Developing Innovations}

Schumpeter $(1939,1997)$, considered the first scholar to address the importance of innovations for the economic development of a society and whose ideas are the underlying theoretical basis of approaches developed since then, characterizes this phenomenon as a process of new combinations in the sense that "produce means to combine materials and forces that are at our disposal [and] producing other things, or the same things with a different method, which means combining these materials and forces differently" (Schumpeter, 1997, p. 76). Thus, innovation is defined as "the creation of a new role of production" (Schumpeter, 1939, p. 84).

Another widespread definition about innovation lies in the Oslo Manual, developed by the Organization for Economic Cooperation and Development (OECD), which presents it as "the implementation of a new or significantly improved product (good or service), or a process, or a new marketing method, or a new method in organizational business practices, workplace organization or external relations" (OECD, 2005, p. 55). This definition highlights the variety of ways in which the innovation process can be represented. In addition, it highlights the need for implementation, defended by Croslin (2010), to characterize the innovations, either by means of their introduction into the market, in the case of product innovations, or for its use by the organization, in the case of process innovations.

According to Berkun (2010), the starting point of all innovation is the biggest question surrounding the innovative process. In this sense, Drucker (2011) argues that innovation is usually trigged by: the unexpected; incongruity; necessity of a process; structural changes in the sector or market; demographic changes; changes in perception; and, finally, new knowledge, either scientific or non-scientific. In addition, Hippel (1988) stated that the sources of innovation must be characterized from its relationship with the other agents, in a functional perspective. Thus, the same innovative agent can act as user, supplier or manufacturer of an innovation, depending on its relationships with the other users and companies.

Dodgson, Gann and Salter (2008) claim that recognizing the sources of an innovation is one of the most important issues for managers, who invest time and resources in the search for these opportunities. The authors pointed out as principal sources of innovation the following: providers, the organization itself and the university, government agencies, academic and commercial publications, commercial and professional associations, exhibitions, conferences, patent analysis, and various networks and communities.

Brynteson (2010) highlights the identification of opportunities as the main source of new technologies. These opportunities, according to Maital and Seshadri (2007), may emerge from changes in terms of users' preferences, market structures and regulations or, in accordance with Marklund, Vonortas and Wessner (2009), originate from the globalization process itself. On the other hand, Sherwood (2002) and Hemlin, Allwood and Martin (2004) emphasize the importance of organizational culture and a creative environment to produce innovations.

Recognizing that such sources do not need to be within the limits of the organization, the open innovation model, presented by Chesbrough $(2003$, 2006), assumes certain fluidity in organizational boundaries. Its main features are the use of knowledge or expertise of individuals from outside the company, utilization of internal and external $\mathrm{R} \& \mathrm{D}$, acquisition of ideas from an external environment, building business models, commercialization and acquisition of intellectual property. This new 
innovation paradigm ends up encouraging the formation of knowledge and technology networks with other organizations. The innovative process becomes, in this way, greater than the organization itself and should no longer be considered as insulated, but rather within the complexity of networks in which it develops.

\section{Social Networks: Characteristics, Typologies and the Influence on the Innovation Process}

The first concept of social networking was proposed by Barnes (1954, p. 44) as "a set of points, some of which are connected by lines", being that the points are people and the lines are representative of their interactions. Since then, other studies have come to use the network approach to analyze social groups. For example, Bott (1957) defined social units as that which maintains contact between its individuals and other groups, and Keck and Sikkink (1999, p. 91) characterized them using "voluntary standards, reciprocal and horizontal communication and exchange".

As Marteleto (2001) warned, a network is not reduced to a simple sum of relationships, because it is able, through how it is organized, to exert influence on these same relationships, changing them. This kind of influence is explained by means of the actor-network theory (Latour, 2000, 2001, 2005). According to this theory, knowledge or scientific fact arises from interactions between elements and actors within these heterogeneous networks, and the role of various actors bring elements to the production of such facts, "because the only way to define an actor is through his performance" (Latour, 2001, p. 143).

Considering their different levels of expertise, Aguiar (2007) distinguishes network actors into three large groups: active nodes, focused nodes, and isolated nodes. The first is characterized by communication initiatives which often feed the network, becoming the major influencers of the other participants. The focused nodes are the actors who receive major information flows in the network. They become the targets of the disseminated messages. Lastly, the isolated nodes are the network's passive participants, which only monitor the information. Thus, the network in essence tends to become an integrated unit, without the presence or imminent need for a center, also noted by Loiola and Moura (1997), but with the ability to configure itself by adding new actors and dropping the redundant nodes, since all constituent nodes of the network should cooperate with their performance.

Various typologies are built around the social networks' social characteristics, such as: objectives, types of actors, configuration, pattern of information exchange, etc. Table 1 below presents the main typologies developed in this sense.

Table 1

Main Typologies of Social Networks

\begin{tabular}{lll}
\hline Authors & Typologies & Characteristics \\
\hline Burt (1992) & Exclusive & Small network, formed by strong ties \\
& Entrepreneurial & Large network, formed by weak ties \\
\hline $\begin{array}{l}\text { Wasserman and } \\
\text { Faust (1994) }\end{array}$ & One-mode & $\begin{array}{l}\text { Made of a single group of actors, for example, the friendship between } \\
\text { neighbors. }\end{array}$ \\
& Two-mode & $\begin{array}{l}\text { Made of one group of actors, as in the relationships between companies } \\
\text { and non-profit organizations }\end{array}$ \\
& Ego-centered & $\begin{array}{l}\text { Consists of a central actor, called ego, and a group of other actors that } \\
\text { maintain a relationship with him. }\end{array}$ \\
\hline
\end{tabular}


Table 1 (continued)

\begin{tabular}{|c|c|c|}
\hline Authors & Typologies & Characteristics \\
\hline \multirow[t]{2}{*}{ Barabási (2003) } & Random & Homogeneous, with most nodes with the same number of relationships \\
\hline & Scale-free & $\begin{array}{l}\text { Heterogeneous, with many nodes presenting few relationships and only } \\
\text { some nodes with a higher number of relationships. }\end{array}$ \\
\hline \multirow{4}{*}{$\begin{array}{l}\text { Costa, Junqueira, } \\
\text { Martinho, and } \\
\text { Fecuri (2003) }\end{array}$} & Thematic & $\begin{array}{l}\text { These work with themes that justify their organization and are } \\
\text { surrounded by participants as defense networks in their infancy. }\end{array}$ \\
\hline & Territorial & $\begin{array}{l}\text { These work on a geographic level. It can be a region, a city, an } \\
\text { environmental protected area, etc. }\end{array}$ \\
\hline & $\begin{array}{l}\text { Information } \\
\text { Exchange }\end{array}$ & $\begin{array}{l}\text { These mainly use the internet to promote the exchange of news and } \\
\text { knowledge. }\end{array}$ \\
\hline & Operational & $\begin{array}{l}\text { These perform research activities and studies, capture, distribution of } \\
\text { resources, provision of services, and production. }\end{array}$ \\
\hline \multirow[t]{3}{*}{ Gloor (2006) } & Innovation & $\begin{array}{l}\text { These focus on the innovation development by using new insights of } \\
\text { innovative groups. }\end{array}$ \\
\hline & Learning & $\begin{array}{l}\text { These search for better knowledge management practices by sharing } \\
\text { them between specialists and requesters. }\end{array}$ \\
\hline & Interests & $\begin{array}{l}\text { These are formed predominantly by a few specialists and people who } \\
\text { require the knowledge. }\end{array}$ \\
\hline \multirow[t]{4}{*}{ Aguiar (2007) } & Tree & $\begin{array}{l}\text { The information starts from a point and is distributed by links in a } \\
\text { unilateral process. }\end{array}$ \\
\hline & Mesh or plot & The information flows without knowing its origin or destiny. \\
\hline & Web & $\begin{array}{l}\text { Networks made of leadership that distribute received information from } \\
\text { any actor to the other network actors. }\end{array}$ \\
\hline & Rhizome & $\begin{array}{l}\text { The information can start from any point and go to any other specific } \\
\text { point or to all of them. }\end{array}$ \\
\hline
\end{tabular}

Note. Source: Prepared by the authors.

With regard to the innovative process, cooperation networks permit organizations to leverage external innovation capacity, as Marklund et al. (2009) and Silva, Raposo, Ferrão and Moreno (2005), assert. The resulting innovation is classified by $\operatorname{OECD}(2005, \mathrm{p} .27)$ as collaborative innovation, which "requires active cooperation with other companies or research institutions in technological activities".

In this respect, Parashar (2007) argues that cooperation networks play a key role in the construction of true knowledge reservoirs. This phenomenon develops through relationships outside the Organization's boundaries, making all this knowledge in these relationships, whether formal or informal, become part of the Organization's total knowledge. According to Hussler and Rondé (2009, p. 2):

What really matters to innovate is the ability to execute cooperative relations and integrate it in a dynamic network (local or regional) of innovative actors. Hence organizations not only need to open their innovative processes as ideas floating around in the environment. They also have to work to build and manage a rich set of active network connections and relationships so as to be able to make use of the research and development that may be outside of its borders. 


\section{Innovations in Biotechnology Networks}

Even though the biotechnology sector is an industry whose innovations are heavily driven by basic research discoveries, the evaluation of the innovative process in the biotechnology sector should not be considered from a linear perspective of science push. This is because this type of analysis is limited in terms of the broader institutional context. In this sense, Silveira, Futino and Olalde (2002) argue for the development and use of new analytical instruments for the sector, especially those involving social network analysis tools, which would enable a better analysis of its complexity.

One of the elements introduced by this kind of analysis relates to scientific activities and academic institutions, where these innovations are in an early development stage. Even in the 1990's, Bonacelli (1993) defended the formation of cooperation networks as a relevant factor for the biotechnology industry growth. This is a result of the sector's inherent conditions, such as high risk associated with investment in new technology and a broad and fragmented knowledge base. Therefore biotechnology projects, as a general rule, can hardly be developed by a single agent.

In light of these characteristics, the tendency for partnership and network formation by companies in the biotechnology sector can be more easily perceived. In a comparative study of domestic and multinational biotechnology companies operating in Brazil, Severino and Telles (2001) expose these organizations working with universities and research centers, especially in activities related to $\mathrm{R} \& \mathrm{D}$, as common practice. This is the first step towards the formation of networks in the industry. A similar picture was seen in the study of Judice (2006), conducted with 42 biotech companies in the state of Minas Gerais, where half of the organizations surveyed have business partnerships and internal trade networks in the country and a third develop collaborative relationships and technological partnerships with Brazilian universities and research centers. This is not to mention the international collaborative networks and partnerships with the United States or Spain, for example.

Such evidence, however, is not sufficient to represent a total overcoming of the difficulties in cooperation network development in the Brazilian biotechnology sector. According to Azevedo, Ferreira, Kropf, and Hamilton (2002), the difficulties for the viability of such networks would be related, among other reasons, to domestic businesses' continued low investment in R \& D, as well as a self-centered orientation by public research centers and institutes that do research while establishing few links with national companies, and an inadequate funding structure for investment in innovation in companies, since the majority of governmental resources for science and technology are directed only to the scientific community.

In this regard, there are also few studies that analyze the formation and operation of these networks, especially those formed by research institutions, whose produced knowledge is essential for the development of innovations in the sector. This is because the vast majority of studies have focused only on interorganizational networks in the sector, for example, the research by Sá, Bomtempo and Quental (1998) conducted on 226 companies located in the South and Southeast region of the country. Only more recent studies have given more prominence and importance to the role of knowledge networks, conducting empirical studies of these networks in order to understand the extent of their role and expertise. An example of this is the study submitted by Aerni (2006), done on the Cassava Biotechnology Network, which operates in Latin America and several countries around the world. In Brazil, Lopes and Judice (2010) conducted research on eight formal networks that integrate the biotechnology center of the state of Minas Gerais. In this case, the incentive for developing networks in this sector comes from public resources and government agencies. 


\section{Methodological Aspects}

This work is based on qualitative approach principles that are exploratory and descriptive. To meet the proposed research objective, the biotechnology sector network's types and properties are analyzed with regard to their relationships, research attributes and performance and innovation production of the chosen empirical field, the Northeast Network of Biotechnology (Renorbio).

Renorbio consists of a biotechnology sector network formed by educational institutions, research laboratories and companies, which aims to foster the development of research and products in the biotechnology area. In addition to motivational factors related to the theme and objective proposed for this study, it was chosen due to the relevance of its activities in promoting biotechnology research and innovation, which made it a reference in its region. With focus on the northeastern region of Brazil, its activities are directed at establishing and encouraging a critical mass of professionals in the region with expertise in biotechnology and related fields to carry out research, development and innovation of importance for the development of the region, using state-of-the-art instruments and scientific expertise for the development of these actions.

Thus, its main focus lies in the Postgraduate Studies Center, and has a multi-institutional character, which involves more than 30 institutions in the region, with a fixed group of nearly 60 $\mathrm{PhD}$ 's. In addition, it has countless other collaborators, doctorate-level student researchers and a solid scientific and technical base in the areas of agricultural biotechnology, natural resources, health and industry, able to act in distinct markets, such as teaching, research, provision of service and industry. Consequently, it is expected that there will be a gradual consolidation of biotechnology centers of excellence in the region, bringing together their expertise to make full use of their resources. In addition, the benefits tend to reach the biotech industry in the Northeast through networked cohesion action, resulting in a structural process according to global competitiveness standards.

As regards to research method used, this study is characterized as a desk research as defined by Godoy (1995), which differs from bibliographic research only in the aspect that Gil (2010, p. 30) calls a "nature of the sources". In this case, the sources used were patents reports developed by actors (researchers or institutions) who were part of Renorbio over the past five years, including institutional documents and those which bring forth specific information regarding research and development efforts for innovation. The information extracted from these reports were grouped and considered according to four categories or levels of analysis: researchers; institutions (laboratories and companies); research areas; and potential markets.

Categories were organized and analyzed using social network analysis software Ucinet (version 6.2). Thus, the relationships between the actors, research areas and potential markets pointed out in the patent data selected were used in the construction of square matrices that represent these relationships. The principal properties of the network and its actors were analyzed based on these matrices related to the interactions of the various actors in a network, as described in Table 2.

Table 2

\section{Main Indicators for Social Network Analysis}

\begin{tabular}{ll}
\hline Indicators & Description \\
\hline Density & $\begin{array}{l}\text { This shows the relationship between the number of existing connections and the } \\
\text { number of possible connections in network. }\end{array}$ \\
Degree of centrality & This consists of a number of actors with whom one actor is directly related. \\
\hline
\end{tabular}


Table 2 (continued)

\begin{tabular}{ll}
\hline Indicators & Description \\
\hline Centralization index & $\begin{array}{l}\text { This concerns a special condition in which one actor plays a role that is clearly } \\
\text { central because it is highly connected to the network. }\end{array}$ \\
Degree of intermediation & This is about a possibility that an actor mediates communication between node pairs. \\
Degree of proximity & This is about an actor's capacity to reach all nodes in a network.
\end{tabular}

Note. Source: Alejandro, V. A. O., \& Norman, A. G. (2005). Manual introdutório à análise de redes sociais. Retrieved from http://www.aprende.com.pt/fotos/editor2/Manual\%20ARS\%20\%5BTrad\%5D.pdf

These interactions were also represented graphically for analysis using NetDraw (version 2.0) software in order to have an overview of the network in question, classifying it according to the various known typologies and assessing the role of each actor in the perceived interactions.

\section{Presentation and Analysis of the Results}

Using the information obtained in the 37 considered patent reports, it was possible to analyze Renobio's characteristics from the macro level of the Brazilian states that house the network, through a medium level of Renobio's institutions and laboratories, and finally the micro level analysis focused on the researchers participating in the network. Table 3 provides information relating to the Brazilian states that harbor laboratories or companies identified in the survey.

Table 3

\section{Characterization of Patents Developed by Renorbio}

\begin{tabular}{|c|c|c|c|c|c|}
\hline \multirow{2}{*}{ States } & \multicolumn{3}{|c|}{ Application Areas } & \multirow{2}{*}{$\begin{array}{l}\text { Number of } \\
\text { patents }\end{array}$} & \multirow{2}{*}{$\begin{array}{l}\text { Number of } \\
\text { laboratories or } \\
\text { companies }\end{array}$} \\
\hline & Farming & Industrial & Health & & \\
\hline Paraíba & - & 6 & 4 & 10 & 3 \\
\hline Ceará & 2 & 1 & 6 & 9 & 10 \\
\hline Pernambuco & 1 & - & 5 & 6 & 3 \\
\hline Bahia & - & 3 & 2 & 5 & 11 \\
\hline São Paulo & - & - & 5 & 5 & 4 \\
\hline Piauí & - & 1 & 2 & 3 & 4 \\
\hline Sergipe & - & - & 3 & 3 & 4 \\
\hline Alagoas & - & 1 & 1 & 2 & 3 \\
\hline Maranhão & - & - & 2 & 2 & 1 \\
\hline Espírito Santo & - & - & 1 & 1 & 2 \\
\hline Rio Grande do Norte & - & - & 1 & 1 & 1 \\
\hline Roraima & - & 1 & - & 1 & 1 \\
\hline
\end{tabular}

Note. Source: Prepared by the authors.

As shown in Table 3, Paraíba and Ceará stand out among the northeastern states in terms of the number of patents. Other states were identified that do not have Renorbio institutions (São Paulo and Roraima), but participated in the development of some patents. With regard to the quantity of 
companies and laboratories participating in the network, the states of Bahia and Ceara stand out, with eleven and ten respectively.

From the consideration of the application area under which innovation efforts are focused within each core network innovation, it is possible to encourage relationship building and strengthening with other research centers in equivalent study areas, culminating in a sum of strategic efforts. According to the data, operations in the states of Ceará and Pernambuco were the only ones with production of agricultural application patents. In the industrial area, the states of Paraíba and of Bahia stand out, with six and three patents, respectively. Finally in the health area, which has the largest number of patents, the states of Ceará and Pernambuco lead in the number of patents, followed by Paraíba.

\section{Institution and researcher networks}

Starting with the biotechnology research firms and laboratories category, the network built from the selected patents for this research consists of 43 departments or laboratories with a university connection and only four companies. Figure 1, as follows, presents these actors as well as the links between them.

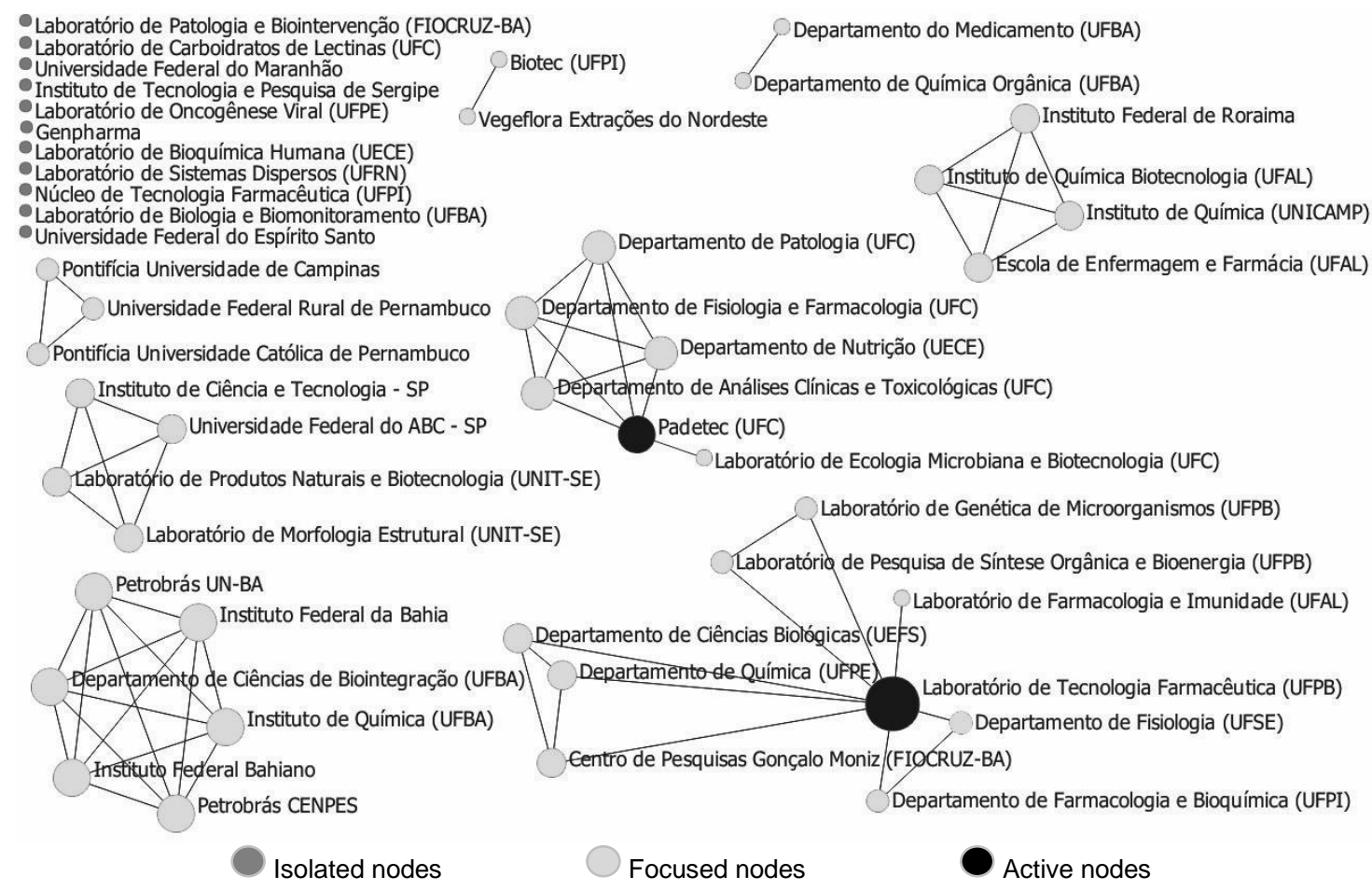

Figure 1. Laboratory and Company Networks of Renorbio.

As visualized in Figure 1, there are eleven actors who find themselves isolated from the others in the network. The other groups are made up of between two to nine actors. The larger number of isolated individuals, when compared to the researcher's network, shows that many of these individuals are at the same laboratory or company, again highlighting the need to foster relationships between the centers. Even in the groups observed, it is possible to perceive a notable tendency of geographic isolation, with the majority of members located in the same state. Thus, the network density of only $31.96 \%$ is insufficient for a concrete exchange between all the nodes.

The actor's centrality degree is enhanced by the number of relationships in the Pharmaceutical Technology Laboratory at UFPB (degree of centrality $=8$ ). The remaining actors have values close to each other. The network centralization index is also quite low (3.84\%), confirming the almost 
nonexistence of central actors when taking into account the entire network. The degree of intermediation also reinforces this characteristic, showing only two of the forty-five actors with this property information transmission between groups. This includes the UFPB's Pharmaceutical Technology Laboratory of UFPB and UFC's Padetec, each standing out with varying degrees of intermediation at 46 and 4, respectively. Finally, as the network is not entirely connected, it is not possible to calculate for the whole network the degree of proximity, which is the capacity of an actor to connect to all other actors of the network. Its calculation was done considering the small groups, obtaining an average value of 2.894 , which supports a perception of weak movement in benefits integration between the participating network institutions.

The researchers' network was built from the 37 selected patents for analysis and consisted of 117 actors. Figure 2 graphically shows the links between these researchers as represented by their initials, highlighting the strength of their relationships and the more central actors of the network.

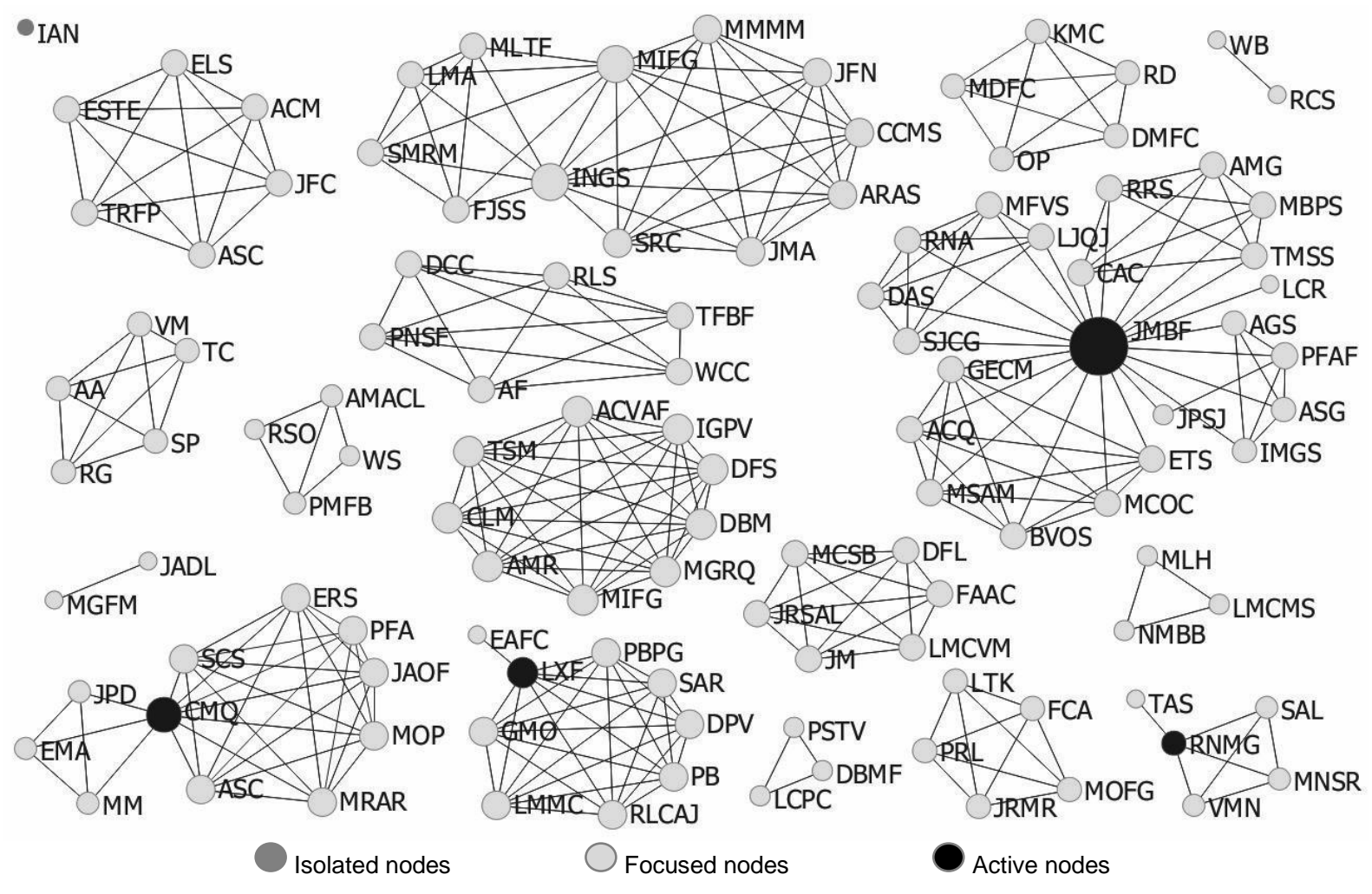

Figure 2. Researchers' Network of Renorbio.

The network configuration is constituted from 17 heterogeneous groups, ranging from two to twenty-three researchers, including an isolated actor. Therefore its density is rather weak (23.29\%), highlighting the need to encourage more links between its members; as was also observed in the analysis at the institutions' level. Consequently, the actors' degree of centrality, which is the number of links they have, also shows a deficiency. This property can be seen in the dimensions of nodes representing actors. Thus, the bigger the node, the greater the degree of centrality. However, what is observed is a large amount of nodes with few links, with only three actors having more than ten connections (JBMF, INGS and MFIG with 22, 11 and 11 relationships, respectively).

As for the centralization index indicating a tendency of some network members to connect to everyone else, it was found to be close to zero $(3.74 \%)$, reinforcing isolation characteristics between the groups by the absence of active actors who move between them. The degree of intermediation, which points out the key actors for information transmission across the network, shows only four actors who have some evidence of activity in this regard (JBMF, RNMG, LXF and CQM). The degree of proximity, whose average was 7.115 despite being above what was observed at the institutional 
level, reinforces the perception of high network fragmentation, which counts on the presence of a few actors who play a strong role in information distribution, but only within their group.

The absence of individuals circulating in more than one research group or that promote this relationship between these groups can be an aspect that deserves to be looked at. Some actors who hold a central role in smaller networks may indicate individuals who tend to act as links between the different groups.

\section{Research areas and potential markets}

The last two categories observed in this study tend to reflect network activities regarding the research areas in which groups are developing their production efforts as well as targeted market agents for their product innovation.

In relation to the research activities, Figure 3 exposes to which areas these activities are directed, highlighting the strongest ones in terms of the number of projects that were developed in its field.

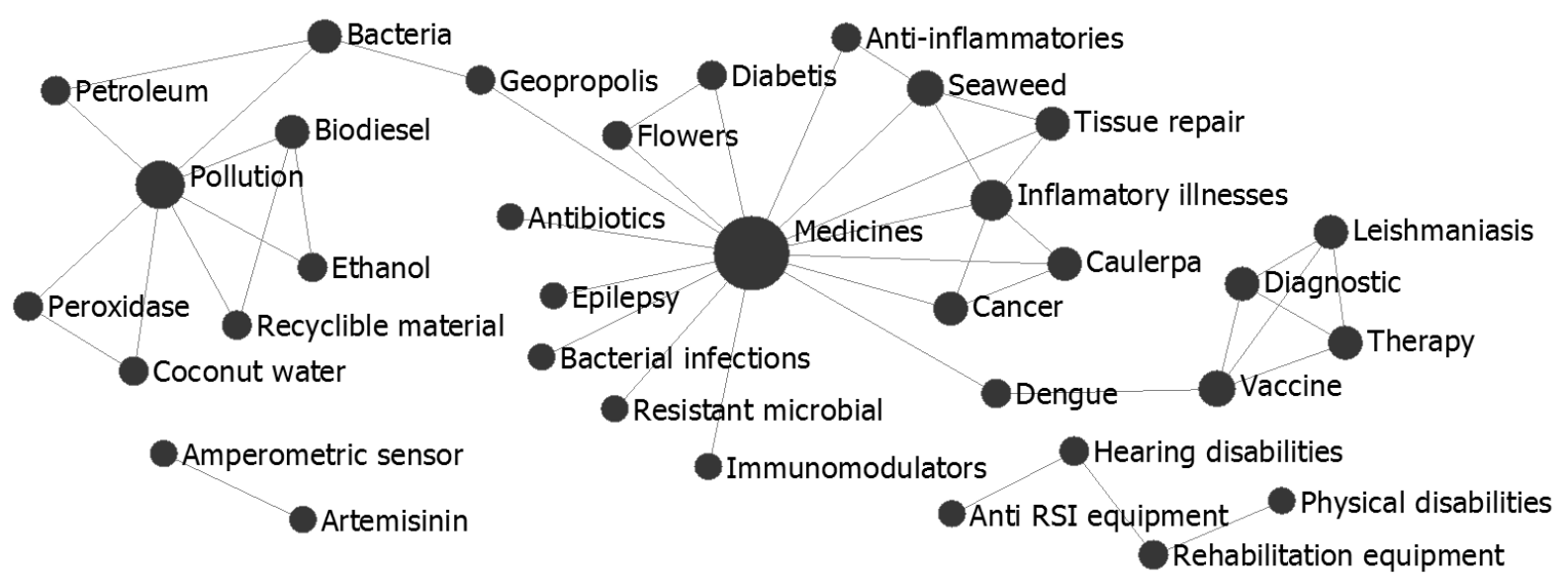

Figure 3. Principal Research Areas at Renorbio.

Research into medicinal products, mainly related to tissue repair, stands out as the strongest research area. Another important niche includes studies aimed at the reduction of emission of pollutants in industrial processes, through the use of improvements in biodiesel or ethanol. Research in the area of inflammatory diseases and the development of vaccines for diseases such as dengue fever and leishmaniasis also stand out.

Figure 4 shows an itemization of the potential markets for the products generated by the research and development in the network.

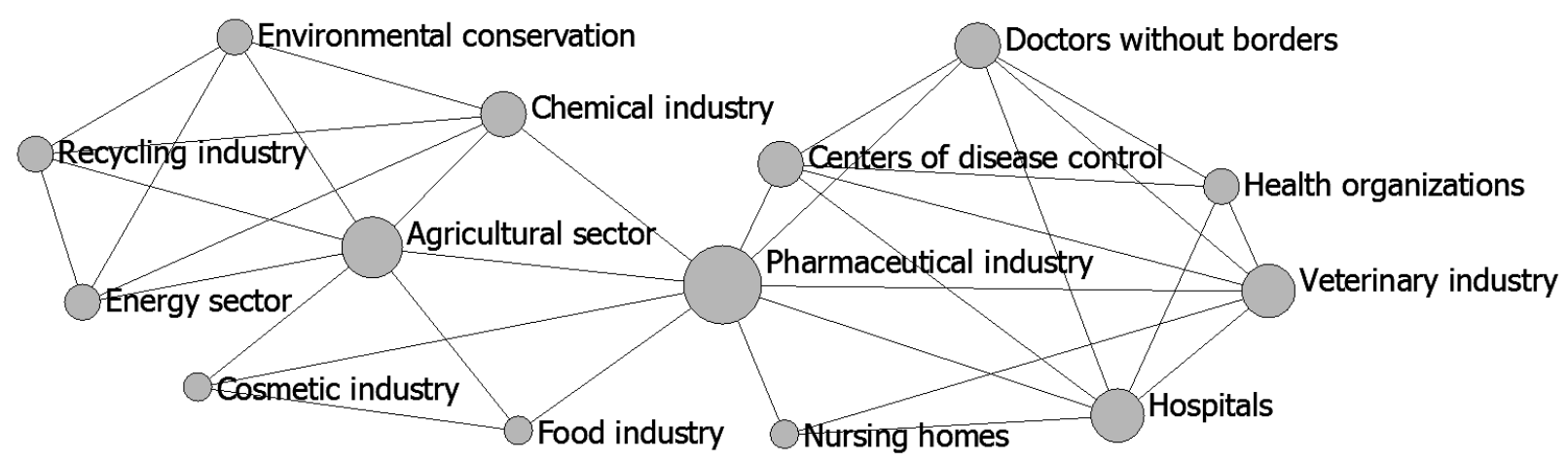

Figure 4. Potential Markets for Products Developed by Renorbio. 
Fourteen markets, which were responsible for hosting the survey results carried out by the network, were highlighted in the patent reports. Of these, the pharmaceutical industry appears to be the most important, most likely as a reflection of the large amount of research on medicinal products. Along with it are the veterinary industry, hospitals, health organizations, disease control centers, doctors without borders and nursing homes.

Another centerpiece as a potential market is the agricultural sector which, although not affected directly, assimilates much of the research conducted with a view of other markets, such as the energy sector, chemical industry, recycling industry and environmental conservation, with regard to improvements in its production processes.

\section{Results discussion}

As a network geared toward basic science and innovations production in biotechnology, Renorbio presented, beginning with analyses previously shown, some features that are noteworthy, especially in relation to typologies presented in the theoretical reference of this research. Beginning with the arrangement constructed and presented in Figures 1 and 2, Renorbio can be classified as a scale-free network, according to a model by Barabási (2003), which has the heterogeneity of their relationships as a main characteristic; i.e., many actors with few relationships and fewer actors end up concentrating the higher quantity of relationships.

As to the process of information dissemination, it was observed from the relationships built between the actors that this resembles the mesh model presented by Aguiar (2007), whose main features are the absence of a central point that is the source of the information and the symmetry of information transferred. This absence may be evidenced by low levels of centralization. According to Alejandro and Norman (2005), these low values are sufficient to indicate the absence of an actor who performs as a central role in the network, being connected directly to all other nodes.

In the laboratory network, only the Pharmaceutical Technology Laboratory (UFPB) showed a characteristic similar to this kind of central actor, playing a linking role between four other research groups, formed by eight other laboratories. In the researchers' network, the same feature could be observed in the JMBF actor, who is acting as an intermediary between four research groups. The other network actors who do not act isolated only show characteristics of focus nodes and are only important in its sub-networks and not for the formation of the network as a whole.

Given the little recurrence of relationships between the actors, since the majority of the relationships are limited to only the production of a patent, Renorbio consists predominantly of weak ties. This aspect is supported by the distinction that Burt (1992) presents between exclusive and corporate networks, the latter being the model which fits Renorbio, whose main features are the size and fragility of their ties. The calculated density indices for Renorbio support this affirmation, being much larger for exclusive networks and with fewer constituting actors. However, it is recognized that this analysis was limited only to interactions on the production of patents, which are not the only form of relationships developed by its agents. In this sense, it is possible that an analysis of informal relationships or interactions of these researchers in research groups, for example, might provide evidence of a different result.

Having its focus concentrated in the graduate center, but still producing a considerable number of patents that represent future innovation possibilities, Renorbio also has aspects of both types of networks. Those presented by Gloor (2006) are the learning collaborative network, whose focus is the sharing of knowledge between specialists and students; and the collaborative innovation network, whose objective is the production of innovations by groups of innovative individuals, in the case of researchers participating in the network. In addition, its work directed toward the biotechnology sector and its concentration on the states in the county's northeast region represent a common characteristic of the thematic and territorial networks presented by Costa, Junqueira, Martinho, and Fecuri (2003). 
In regard to its research activities, the mapping of the research areas identified in the patents reports used for this study identified 34 distinct areas, with the medicinal products area standing out as having the highest concentration of innovation efforts. It is noteworthy that the term efforts of innovation, used in relation to patents developed in the network, refers to the concept of innovation built into this study (Croslin, 2010; OECD, 2005), which highlights the importance of implementation so that something new will be considered an innovation. Thus, just as patents represent these new things in terms of product possibilities or services, they shall, for the purposes of this research, be considered only as potential innovations.

\section{Final Considerations}

Analysis of 37 patents developed by Renorbio and considered for this study aimed at investigating a biotechnology sector network's properties and types with regard to their relationships, attributes and performance in research and innovations production. To do so, the first research step was the identification of actors, groups, institutions, research areas and projects developed by the network. In total, 117 researchers were identified, distributed across 18 research centers and 47 laboratories or companies. Their projects were distributed in three main areas: agriculture, industrial and health, the latter being the strongest of the three, with more patents produced and more institutions involved in research.

In order to track the relationship networks between members, groups, institutions and projects, social networking analysis tools were used, making it possible to construct relationship matrices between laboratory and companies and, lastly, researchers. From these matrices, and with the aid of Ucinet and Netdraw software, these relationship matrices could be analyzed and represented graphically in the form of networks. This makes it possible to realize the role of each actor within the innovation search activities, and thus distinguish them as active, isolated or focused nodes according to Aguiar's typology (2007). However, the presence of any actor with global activities in the network was not apparent.

The presence of isolated nodes shows a need for integration strategies. The lack of a center to promote integration of the various groups was perceived, possibly because this member agent might set up a management unit. However, rather than a centralization agent, considered unnecessary by Loiola and Moura (1997), by strengthening the most active agents found in a network it is possible to include even the isolated members, making the network an essentially integrated unit.

In fact, the importance of an actor within any social networks is known. In this case, a network that has a knowledge transfer and innovation production purpose, occurs, not only by isolated action, but by their performance along with other actors. Their activities are therefore evaluated in relation to other actors. Thus, another observed aspect was the fragility of relationships between the actors, which were repeated a few times in more than one research project. This would be a common characteristic of entrepreneurial networks, according to Burt (1992), which is caused by the larger size of this type of network.

After this network construction step, the analysis of network properties was done, characterizing its typology, relationships, roles and attributes and knowledge production. Therefore, the main indicators of social network analysis (degrees of density, centrality, centralization, intermediation and proximity) were used to give indications of these characteristics. The weak density presented by the network at all analysis levels strengthens the necessity for integration strategies and indicates the possibility for new relationships between the agents that are still isolated.

Finally, it was possible to understand trends in biotechnology research developed by Renorbio, as well as the type of result that it hopes to promote in targeted markets. These trends were observed 
while taking into consideration the identification of innovation effort by means of mapping the research areas and potential markets in the biotechnology dissemination and application sectors.

In this way, this study's main objective was achieved by using patent data, not as innovation measurement mechanisms, but as instruments for the construction of this scenario and innovative process. This methodology showed to be quite satisfactory for bringing countless possibilities of analysis and study which tend to contribute to the theme's development and, specifically, to the sector studied. The importance of these innovative efforts to the economy, which could still be strengthened, are inserted in view of expectations that such biotechnological promises carry.

However, the production of innovations in biotechnology networks is an emerging theme and therefore is still far from being exhausted. This research is more of an initial effort in this field, building on the context of the Brazilian economy, rather than a definitive study of their specific features. In this way, new studies are necessary to deepen the analysis presented here, especially with regard to the development process of these innovations through specific case studies. Therefore, it is possible to construct models displaying the trajectories of innovations disseminated from the networks into the market, which highlight, among various aspects, main sources of innovation, barriers, agents driving the process and the importance for the creation of new companies.

\section{References}

Aerni, P. (2006). Mobilizing science and technology for development: the case of the Cassava Biotechnology Network (CBN). AgBioForum, 9(1), 1-14.

Aguiar, S. (2007). Redes sociais na internet: desafios à pesquisa. Anais do Congresso Brasileiro de Ciências da Comunicação, Santos, SP, Brasil, 30.

Alejandro, V. A. O., \& Norman, A. G. (2005). Manual introdutório à análise de redes sociais. Retrieved from http://www.aprende.com.pt/fotos/editor2/Manual\%20ARS\%20\%5BTrad\%5D.pdf

Azevedo, N., Ferreira, L. O., Kropf, S. P., \& Hamilton, W. S. (2002). Pesquisa científica e inovação tecnológica: a via brasileira da biotecnologia. DADOS - Revista de Ciências Sociais, 45(1), 139176.

Barabási, A.-L. (2003). Emergence of scaling in complex networks. In S. Bornholdt \& H. G. Schuster (Eds.), Handbook of graphs and networks: from the genome to the internet (Cap. 3, pp. 69-84). Weinheim: Wiley-VCH.

Barnes, J. A. (1954). Class and committees in a norwegian island parish. Human Relations, 7(1), 3958. doi: $10.1177 / 001872675400700102$

Berkun, S. (2010). The myths of innovation. Canada: O'Reilly.

Bonacelli, M. B. M. (1993). Determinantes da evolução da biotecnologia nos anos 90: a cooperação empresarial. Cadernos de Ciência \& Tecnologia, 10(1/3), 72-92.

Bott, E. (1957). Family and social network. London: Tavistock Publications.

Brynteson, R. (2010). The manager's pocket guide to innovation. Amherst, MA: HRD Press.

Burt, R. S. (1992). Structural holes: the social structure of competition. Cambridge, MA: Harvard University Press. 
Chesbrough, H. W. (2003). The era of open innovation. MIT Sloam Management Review, 44(3), 3442.

Chesbrough, H. W. (2006). Open innovation. Boston, MA: Harvard Business School.

Costa, L., Junqueira, V., Martinho, C., \& Fecuri, J. (Coords.). (2003). Redes: uma introdução às dinâmicas da conectividade e da auto-organização. Brasília, DF: WWF-Brasil.

Croslin, D. (2010). Innovate the future: a radical new approach to IT innovation. Boston, MA: Prentice Hall.

Dodgson, M., Gann, D., \& Salter, A. (2008). The management of technological innovation: strategy and practice. New York: Oxford University Press.

Dosi, G. (1988). The nature of the innovative process. In G. Dosi, C. Freeman, R. Nelson, G. Silverberg, \& L. Soete (Eds.), Technical change and economic theory (Cap. 10, pp. 221-238). London, Francis Pinter and New York: Columbia University Press.

Drucker, P. F. (2011). Inovação e espírito empreendedor: prática e princípios. São Paulo: Cengage Learning.

Fagerberg, J. (2005). Innovation: a guide to the literature. In J. Fagerberg, D. C. Mowery, \& R. R. Nelson (Eds.), The Oxford handbook of innovation (Cap. 1, pp. 1-26). Oxford: Oxford University Press.

Freeman, C., \& Perez, C. (1988). Structural crises of adjustment, business cycles and investment behavior. In G. Dosi, C. Freeman, R. Nelson, G. Silverberg, \& L. Soete (Eds.), Technical change and economic theory (Cap. 3, pp. 38-66). London, Francis Pinter and New York: Columbia University Press.

Gil, A. C. (2010). Como elaborar projetos de pesquisa (5th ed.). São Paulo: Atlas.

Gloor, P. A. (2006). Swarm creativity: competitive advantage through collaborative innovation networks. New York: Oxford University Press.

Godoy, A. S. (1995). Pesquisa qualitativa: tipos fundamentais. Revista de Administração de Empresas, 35(3), 20-29. doi: 10.1590/S0034-75901995000300004

Hemlin, S., Allwood, C. M., \& Martin, B. R. (Eds.). (2004). Creative knowledge environments: the influences on creativity in research and innovation. Cheltenham, UK: Edward Elgar.

Hippel, E. (1988). The sources of innovation. New York: Oxford University Press.

Hussler, C., \& Rondé, P. (2009). Investing in networking competences or establishing in hot spots? Journal of Technology Management \& Innovation, 4(4), 1-13. doi: 10.4067/S071827242009000400001

Judice, V. M. M. (2006). Competências em internacionalização e inovação em biotecnologia no Brasil. Journal of Technology Management \& Innovation, 1(4), 95-107.

Keck, M. E., \& Sikkink, K. (1999). Transnational advocacy networks in international and regional politics. International Social Science Journal, 51(159), 89-101. doi: 10.1111/1468-2451.00179

Latour, B. (2000). Ciência em ação: como seguir cientistas e engenheiros sociedade afora. São Paulo: Editora Unesp.

Latour, B. (2001). A esperança de Pandora: ensaios sobre a realidade dos estudos científicos. Bauru, SP: EDUSC. 
Latour, B. (2005). Reassembling the social: an introduction to actor-network-theory. New York: Oxford University Press.

Loiola, E., \& Moura, S. (1997). Análise de redes: uma contribuição aos estudos organizacionais. In T. Fisher (Org.), Gestão contemporânea, cidades estratégias e organizações locais (Cap. 3, pp. 53-68). Rio de Janeiro: Fundação Getúlio Vargas.

Lopes, A. L. M., \& Judice, V. M. M. (2010). Redes cooperativas de pesquisa científica e tecnológica para a inovação: a biotecnologia mineira em foco. Revista de Administração e Inovação, 7(4), 4-20. doi: 10.5585/RAI.2010320

Maital, S., \& Seshadri, D. V. R. (2007). Innovation management: strategies, concepts and tools for growth and profit. London: Response Books.

Marklund, G., Vonortas, N. S., \& Wessner, C. W. (Eds.). (2009). The innovation imperative: national innovation strategies in the global economy. Cheltenham, UK: Edward Elgar.

Marteleto, R. M. (2001). Análise de redes sociais: aplicação nos estudos de transferência da informação. Ciência da Informação, 30(1), 71-81.

Nelson, R., \& Winter, S. G. (1982). An evolutionary theory of economic change. Cambridge: Belknap Press.

Organisation for Economic Co-Operation and Development. (2005). Manual de Oslo: diretrizes para coleta $e$ interpretação de dados sobre inovação. Retrieved from http://www.oei.es/salactsi/oslo2.pdf

Parashar, M. (2007). 8 steps to building innovating organizations. New Delhi: Response Books.

Pavitt, K. (1990). What we known about the strategic management of technology. California Management Review, 32(3), 17-26.

Pavitt, K. (2005). Innovation process. In J. Fagerberg, D. C. Mowery, \& R. R. Nelson (Eds.), The Oxford handbook of innovation (Cap. 4, pp. 86-114). Oxford: Oxford University Press.

Rosenberg, N. (2006). Por dentro da caixa-preta: tecnologia e economia. Campinas, SP: Editora da Unicamp.

Sá, M. P., Bomtempo, V. J., \& Quental, C. (1998). Terceirização no processo final na indústria farmacêutica e veterinária. Revista de Administração Contemporânea, 2(2), 85-101. doi: 10.1590/S1415-65551998000200006

Schumpeter, J. A. (1939). Business cycles: a theoretical, historical and statistical analysis of the capitalist process. New York: McGraw-Hill.

Schumpeter, J. A. (1997). A teoria do desenvolvimento econômico. São Paulo: Nova Cultural.

Severino, P., \& Telles, R. (2001). Pesquisa e desenvolvimento em biotecnologia: uma análise comparada de organizações operando no mercado brasileiro. Caderno de Pesquisas em Administração, 8(3), 77-94.

Sherwood, D. (2002). Creating an innovative culture. United Kingdom: Capstone Publishing.

Silva, M. J. M., Raposo, M. L. B., Ferrão, M. E., \& Moreno, J. J. J. (2005). Relacionamentos externos no âmbito da inovação empresarial: modelo aplicado aos avanços inovadores. Portuguese Journal of Management Studies, 10(1), 5-19.

Silveira, J. M. F. J., Futino, A. M., \& Olalde, A. R. (2002). Biotecnologia: corporações, financiamento da inovação e novas formas organizacionais. Economia e Sociedade, 1(11), 129-164. 
Smith, K. (2005). Measuring innovation. In J. Fagerberg, D. C. Mowery, \& R. R. Nelson (Eds.), The Oxford handbook of innovation (Cap. 6, pp. 148-178). Oxford: Oxford University Press.

Tunzelmann, G. N. von (1995). Technology and industrial progress: the foundations of economic growth. Cheltenham, UK: Edward Elgar Publishing.

Wasserman, S., \& Faust, K. (1994). Social network analysis: methods and applications. Cambridge: Cambridge University Press. 